\title{
Antiviral potential of phytoligands against chymotrypsin-like protease of COVID-19 virus using molecular docking studies: An optimistic approach
}

\section{Ratish Chandra Mishra}

Plant Genetics Lab, Department of Genetics, Maharshi Dayanand University, Rohtak-124001, Haryana, India

\section{Rosy Kumari}

Plant Genetics Lab, Department of Genetics, Maharshi Dayanand University, Rohtak-124001, Haryana, India

\section{Shivani Yadav}

Department of Computer Science and Application, Maharshi Dayanand University, Rohtak-124001, Haryana, India

Jaya Parkash Yadav ( $\square$ yadav1964@rediffmail.com )

Plant Genetics Lab, Department of Genetics, Maharshi Dayanand University, Rohtak-124001, Haryana, India

\section{Research Article}

Keywords: COVID-19, 3CLpro, Molecular docking, SwissDock, Phytoligands

Posted Date: April 20th, 2020

DOl: https://doi.org/10.21203/rs.3.rs-23956/v1

License: (a) (i) This work is licensed under a Creative Commons Attribution 4.0 International License.

Read Full License 


\section{Abstract}

A recent outbreak of the novel coronavirus, COVID-19, in the city of Wuhan, Hubei province, China and its ensuing worldwide spread have resulted in lakhs of infections and thousands of deaths. As of now, there are no registered therapies for treating the contagious COVID-19 infections, henceforth drug repositioning may provide a fast way out. In the present study, a total of thirty-five compounds including commonly used anti-viral drugs were screened against chymotrypsin-like protease (3CLpro) using SwissDock. Interaction between amino acid of targeted protein and ligands was visualized by UCSF Chimera. Docking studies revealed that the phytochemicals such as cordifolin, anisofolin A, apigenin 7-glucoside, luteolin, laballenic acid, quercetin, luteolin-4-glucoside exhibited significant binding energy with the enzyme viz. - $8.77,-8.72,-8.36,-8.35,-8.13,-8.04$ and $-7.87 \mathrm{Kcal} / \mathrm{Mol}$ respectively. Therefore, new lead compounds can be used for drug development against SARS-CoV-2 infections.

\section{Introduction}

The emergence of the severe acute respiratory syndrome-associated to COVID-19 as pandemic; presents new challenges to global biomedical research. At current scenario, according to Johns Hopkins University \& Medicine database, the virus has affected 181 countries. As on April 4, 2020, total confirmed cases suffering from COVID 19 were 1,131,713 and 59,884 people have died ${ }^{1}$. The appearance of COVID-19 has also impacted transplantation worldwide ${ }^{2}$. In December of 2019, reports emerged of pneumonia clusters at Wuhan as they were linked to a wet animal wholesale market in the region. After a lot of epidemiologic investigation with International Committee on Taxonomy of Viruses; WHO officially announced identification of corona virus as COVID-19 or SARS-CoV-2 ${ }^{3,4}$. Original diagnostic findings in family cluster cases at China included fever, dry cough, shortness of breath, rhinitis, fatigue, diarrhea, headache, symptoms of pneumonia and low lymphocyte count. Chest CT scans of the patients showed bilateral patchy shades in the lungs 5 .

Coronaviruses are enveloped, $(+)$ single stranded RNA viruses with a crown like appearance, belongs to the family Coronaviridae, order Nidovirales which is further divided into four genera ( $a, \beta, y$ and $\delta$ )," subgenera Sarbecovirus, species is SARS-CoV ${ }^{6}$. Four CoVs commonly found among humans: HCoV2229E, -HKU1, -OC43 and -NL63. Novel CoV-2 is a zoonotic form of the beta-coronavirus which can rapidly mutate and recombine although mutations are natural part of the virus life cycle ${ }^{7,8}$.

COVID-19 usually, has an incubation period of 2-7 days and up to 14 days as longest time from infection to symptoms ${ }^{9}$. Throat swab, nasal swab, sputum, blood samples and stool are tested using viral nucleic acid with different techniques including real-time reverse transcription polymerase chain reaction, wholegenome sequencing, paper-based bio-molecular sensors, nanopore target sequencing, antibody-based immunoassays, and the clustered regularly interspaced short palindromic repeats-Cas system ${ }^{10}$.

Drug development against coronavirus includes inhibition of viral replication through acting on its critical enzymes. As the viral genome (29891nucleotide) encodes more than 20 proteins, among which RNA- 
dependent RNA polymerase, helicase, spike, two proteases (PLpro and 3CLpro) are vital ${ }^{11}$. A large segment of population with the highest mortality from CoV-19 were elder people and individuals with weak immune system ${ }^{12,13}$. Therefore, interferons enhancement, monoclonal antibodies administration actively or passively can improve the immune response against the virus. Zinc is also reported to have antiviral effect by inhibiting CoV RNA polymerase activity and thus decreases viral growth in cell culture set up ${ }^{14,15}$. A receptor-binding domain (RBD) of the spike protein in SARS-CoV, mediates the interaction with host angiotensin-converting enzyme $2(A C E-2)^{16}$. The drug, chloroquine affects the glycosylation process of ACE-2, which is essential for interaction with the host. It increases endosomal pH and thus makes unfavorable environment for the cell/virus fusion ${ }^{17}$.

The treatment with conventional drugs is intricate as multidrug resistance due to accumulating mutations in viruses however natural products provide broad spectrum antivirals agents with minimum side effects ${ }^{18}$. In Ayurveda, several medicinal plants namely; Tinospora cordifolia, Ocimum sanctum, Leucas cephalotes, Allium sativum, Allium cepa, Citrus limon, Piper nigrum, Phyllanthus emblica have been reported for antiviral activities ${ }^{19-21}$. They are endowed with a variety of secondary metabolites such as tannins, terpenoids, flavonoids, flavones, glycosides, alkaloids, phytosteroids and thus, herbal agents can be promising candidates for evaluating their effects on pathogenic microbes ${ }^{22}$. Therefore, the present study aims to analyze the docking potential of predominant phyto-constituents in the reported plants as inhibitors of 193CLpro in search of therapeutic potential against COVID 19 infection.

\section{Results}

In order to identify the new phytoligands with the top-ranking hit; virtual screening was carried out against 3CLpro. Their minimum binding energy values were compared on the basis of their best fitting with the enzyme, $\mathrm{H}$-bond and LD50 value as depicted in Table 1 and Supplementary Table 1. Result indicated that cordifolin displayed minimum docking score whereas sofosbuvir, anisofolin A, apigenin 7-glucoside and luteolin-4-glucoside showed less $\mathrm{LD}_{50}$. Structure of lead molecules and their plant sources have been represented in Fig. $1(\mathrm{a} \& \mathrm{~b})$ and Table 2. Binding affinity and hydrophobic interaction of lead compound with 3 CLpro as shown in Fig. 2 \& 3. Binding interaction of standard drug sofosbuvir with 3CLpro as depicted in Fig. 4.

\section{Discussion}

The 3-chymotrypsin-like protease (main protease, $\mathrm{M}^{\mathrm{pro}}$ ) or non-structure protein (Nsp5) was selected for the study. As it is first automatically cleaved from poly-proteins to produce mature enzymes, and then further cleaves downstream Nsps which is essential in the life cycle of the virus. Most of the lead compound showed hydrophobic interaction with amino acid present at catalytic site of 3CLpro. Catalytic dyad of the enzyme (His41 and Cys145) is located in the gap between domains I and II, and 41, 49, 143$144,163-167,187-192$ amino acid bind with the substrates ${ }^{35,36}$. In the molecular docking study least binding energy revealed the stronger docking between ligands and viral targets. Cordifolin, Anisofolin A, 
Apigenin 7-glucoside, Luteolin, Quercetin and Luteolin-4-glucoside phytochemicals exhibited least binding energy in the present study. Hence, these lead phytochemicals have been reported to exhibit antiviral activities.

Cordifolin which is an oxygenated chalcone exhibited inhibition of HIV protease ${ }^{37}$. Anisofolin A exclusively reported in the flowers of Leucas species found to have promising anti- mycobacterium activity against $M$. tuberculosis $\mathrm{H} 37 \mathrm{Ra}$, antimalarial activity against Plasmodium falciparum (3D7) ${ }^{38}$. The flowers are given in the form of syrup or with honey as a domestic remedy for bronchial asthma, colds, cough ${ }^{39}$. Luteolin which is a flavonoid exhibited potent antiviral activity against SARS coronavirus ${ }^{40}$, Japanese encephalitis virus ${ }^{41}$. It also inhibited HIV-1 protease in cell-free assays ${ }^{42}$. Laballenic acid (Octadeca-5, 6-dienoic acid) is an allenic fatty acid showed the anti-inflammatory effect through the suppression of TNF-a production in macrophages ${ }^{43}$. Quercetin; a natural flavonoid, significantly decreased the viral genome replication of hepatitis $C$ virus ${ }^{44}$. The compound inhibited wide range of influenza strains, including A/FM-1/47/1 (H1N1), A/Puerto Rico/8/34 (H1N1) and A/Aichi/2/68 (H3N2). It also showed significant inhibitory activities against dengue virus ${ }^{45}$. Apigenin 7-glucoside which is a flavone, has represented to induce anti-HIV activity in T-cell line ${ }^{46}$.

Earlier molecular docking on medicinal plants reported that the flavonoid glycosides i.e, diosmin and hesperidin, obtained from Citrus aurantium (citrus fruit) block the substrate binding site $3 \mathrm{CLpro}^{47}$. In a similar study, betulonal from Cassine xylocarpa; andrographolide derivatives from Andrographis paniculata, phyllaemblinol from Phyllanthus emblica, theaflavin 3,3'-di-0- gallate from Camellia sinensis, Stigmast-5-en-3-ol from Swertia binchuanensis was predicted to bind to CLpro with minimum docking energy $^{48}$. Another compound i.e. withanone from Withania somnifera, displayed significant docking with the binding interface of ACE2-RBD complex. ${ }^{49}$ Sofosbuvir which showed least toxicity in the present study is a prodrug nucleotide analogue and has recently been proposed as an antiviral for the SARS$\mathrm{CoV}-2$ based on the similarity between the replication mechanisms of the hepatitis $\mathrm{C}$ virus and the coronaviruses.

The drug is also a protease inhibitor, originally developed against HIV although with little side effects including fatigue and headache. In a study demonstrated in Northeast Chongqing the clinic features and therapies of 135 COVID-19 patients with lopinavir/ritonavir and traditional Chinese medicine played an important role in the treatment of the viral pneumonia ${ }^{50}$.

In addition, as preventive measures, WHO guidelines mainly focuses on social distancing measures such as quarantines, frequent hand wash, use of mask and avoidance of unwanted contact with wild animals or animal products ${ }^{51}$. Like others CoVs, it is sensitive to heat and UV rays, thus drinking hot water may be useful. Other suggested treatment includes providing oxygen inhalations, nutritional support, psychological calmness, maintaining fluids and electrolyte balances of individual ${ }^{52}$. The COVID-19 pandemic has rapidly evolved and changed our way of life in an unprecedented manner. Recent experience with other zoonotic viruses e.g., Middle East Respiratory Syndrome (MERS), Severe Acute 
Respiratory Syndrome (SARS), Ebola Virus Disease (EVD), and Zika Virus (ZIKV) suggests that these types of outbreaks are likely to be recurrent and potentially more frequent.

It is concluded that the lead phytochemicals; Cordifolin, Anisofolin A, Apigenin 7-glucoside, Luteolin, Quercetin and Luteolin-4-glucoside may be used to develop potential antiviral drugs. In future pharmacological research it is necessary to investigate the therapeutic uses of the medicinal plants containing the bioactive compounds.

\section{Methods}

\section{Protein Preparation}

The structure of coronavirus protease used for docking, was retrieved from the RCSB Protein Data Bank (http://www.rcsb.org) with PDB ID 6LU7 and it posses 2 chains (A \& B) which consist of 306 amino acid residues.

\section{Ligand preparation}

Ligand structure were identified with pubchem and drawn in ChemSketch, saved as mdl mol file and then converted into Mol2 file by Avogadro software ${ }^{53}$

\section{Molecular docking}

All computational analyses were carried out on SwissDock, a web server (www.swissdock.ch) to predict the molecular interactions between target protein and phytochemicals. Binding modes were scored using their FullFitness and Clusters were ranked according to the average FullFitness of their elements ${ }^{54}$.

\section{Visualization}

Hydrophobic interactions \& $\mathrm{H}$-bonds between ligands and amino acid of targeted protein were visualized on UCSF Chimera.

\section{Toxicity analysis}

ProTox tool was used to evaluate toxicity of lead molecule ${ }^{55}$.

\section{Declarations}

Acknowledgements 
Ratish Chandra Mishra is thankful to UGC, New Delhi for the award of UGC BSR fellowship (F.25-1/201314).

\section{Author contributions}

Mishra RC designed the study and performed all of the experiments; Kumari R wrote the manuscript; Yadav S analyzed all of the data, assembled the figures and Yadav JP supervised the whole study and revised the final manuscript.

\section{Competing interests}

The authors declare no competing interests.

\section{References}

1. COVID-19 global cases (Johns Hopkins University \& Medicine, USA, 2020); https://coronavirus.jhu.edu/map.html

2. Kumar, D. et al. COVID-19: a global transplant perspective on successfully navigating a pandemic. J. Transplant. https://doi.org/10.1111/ajt.15876 (2020).

3. Choi, K. R., Skrine, J. K. \& Logsdon, M. C. Nursing and the novel coronavirus: risks and responsibilities in a global outbreak. Adv.Nurs. https://doi.org/10.1111/jan.14369 (2020).

4. Radi, G., Diotallevi, F., Campanati, A. \& Offidani, A. Global coronavirus pandemic (2019-nCOV): implication for an Italian medium size dermatological clinic of a ii level hospital. Eur. Acad. Dermatol. https://doi.org/10.1111/jdv.16386 (2020).

5. Lou, X. X., Shi, C. X., Zhou, C. C. \& Tian, Y. S. Three children who recovered from novel coronavirus 2019 pneumonia. Paediatr. Child Health. https://doi.org/10.1111/jpc.14871 (2020).

6. Gorbalenya, A. E. et al. The species severe acute respiratory syndrome-related coronavirus: classifying 2019-nCoV and naming it SARS-CoV-2. Microbiol. 5, 536-544 (2020).

7. Zimmermann, P. \& Curtis, N. Coronavirus infections in children including COVID- Pediatr. Infect. Dis. J. https://doi.org/10.1097/INF.0000000000002660 (2020).

8. Grubaugh, N. D., Petrone, M. E. \& Holmes, E. C. We shouldn't worry when a virus mutates during disease outbreaks. Microbiol. 5, 529-530 (2020).

9. Li, Q. et al. Early transmission dynamics in Wuhan, China, of novel coronavirus- infected pneumonia. Engl. J. Med. https://doi.org/10.1056/NEJMoa2001316 (2020).

10. Liu, , Fu, A., Deng, Z., Li, Y. \& Liu, T. Promising methods for detection of novel coronavirus SARS-CoV2. View https://doi.org/10.1002/viw2.4 (2020).

11. Sarma, et al. Therapeutic options for the treatment of 2019-novel coronavirus: an evidence-based approach. Indian J. Pharmacol. 52, 1-5 (2020).

12. Britton, P. N. \& Marais, B. J. Questions raised by COVID-19 case descriptions. Paediatr. Child Health. https://doi.org/10.1111/jpc.14872 (2020). 
13. Pagano, M. B. et al. Prepare to adapt: blood supply and transfusion support during the first 2 weeks of the 2019 novel coronavirus (COVID-19) pandemic affecting Washington State. Transfusion https://doi.org/10.1111/trf.15789 (2020).

14. Zumla, A., Hui, D. S., Azhar, E. I., Memish, Z. A. \& Maeurer, M. Reducing mortality from 2019-nCoV: host-directed therapies should be an option. Lancet 395, e35-e36 (2020). https://doi.org/10.1016/S0140-6736(20)30305-6

15. Te Velthuis, et al. Zn2+ inhibits coronavirus and arterivirus RNA polymerase activity in vitro and zinc ionophores block the replication of these viruses in cell culture. PLoS pathog. 6, e1001176 (2010).

16. Letko, M., Marzi, A. \& Munster, V. Functional assessment of cell entry and receptor usage for SARSCoV-2 and other lineage B betacoronaviruses. Microbiol. 5, 562-569 (2020). https://doi.org/10.1038/s41564-020-0688-y

17. Vincent, M. J. et al. Chloroquine is a potent inhibitor of SARS coronavirus infection and spread. J. 2, 69 (2005).

18. Chandra, $\mathrm{H}$. et al. Antimicrobial resistance and the alternative resources with special emphasis on plant-based antimicrobials-a review. Plants 6, 1-11 (2017).

19. Pushpa, R., Nishant, R., Navin, K. \& Pankaj, G. Antiviral potential of medicinal plants: an overview. Res. J. Pharm. 4, 1-8 (2013).

20. Mittal, J., Sharma, M. M. \& Batra, A. Tinospora cordifolia: a multipurpose medicinal plant-a review. Med. Plants Stud. 2, $32-47$ (2014).

21. Rege, A. A. \& Chowdhary, A. S. Evaluation of Ocimum sanctum and Tinospora cordifolia as probable HIV protease inhibitors. J. Pharm. Sci. Rev. Res. 25, 315-318 (2014).

22. Choudhary, A. K., Sunojkumar, P. \& Mishra, G. Fatty acid profiling and multivariate analysis in the genus Leucas reveals its nutritional, pharmaceutical and chemotaxonomic significance. Phytochemistry, 143, 72-80 (2017).

23. Kamal, M., Arif, M. \& Jawaid, T. Adaptogenic medicinal plants utilized for strengthening the power of resistance during chemotherapy-a review. Pharm. Exp. Med. 17, 1-18 (2017).

24. Das, S. N., Patro, V. J. \& Dinda, S. C. A review: ethnobotanical survey of genus Leucas. Rev. 6, 100106 (2012).

25. Ashour, M. A. G. New diacyl flavonoid derivatives from the Egyptian plant Blepharis edulis (Forssk.) Pers. Fac. Pharm. Cairo Univ. 53, 11-17 (2015).

26. Miean, K. H. \& Mohamed, S. Flavonoid (myricetin, quercetin, kaempferol, luteolin, and apigenin) content of edible tropical plants. Agr. Food. Chem. 49, 3106-3112 (2001).

27. Ali, F., Rahul, Naz, F., Jyoti, S. \& Siddique, Y. H. Health functionality of apigenin: a review. J. Food Prop. 20, 1197-1238 (2017).

28. Khaerunnisa, S., Kurniawan, H., Awaluddin, R., Suhartati, S. \& Soetjipto, S. Potential inhibitor of COVID-19 main protease (Mpro) from several medicinal plant compounds by molecular docking study. https://doi.org/10.20944/preprints202003.0226.v1 (2020). 
29. Verma, A., Kumar, A., Upreti, D. K., Pande, V. \& Pal, M. Fatty acid profiling and In vitro antihyperglycemic effect of Leucas cephalotes (Roth) spreng via carbohydrate hydrolyzing enzyme inhibition. Mag. 13, S22-S25 (2017).

30. Ohigashi, H. Studies on the biologically active substances of Sapium japonicum (Euphorbiaceae). Bull. Inst. Chem. Res. Kyoto Univ. 50, 239-274 (1973).

31. Sharma, D., Rani, R., Chaturvedi, M., Rohilla, P. \& Yadav, J. P. In silico and in vitro approach of Allium cepa and isolated quercetin against MDR bacterial strains and Mycobacterium smegmatis. Afr. J. Bot. 124, 29-35 (2019).

32. Dabeek, W. M. \& Marra, M. V. Dietary Quercetin and Kaempferol: bioavailability and potential cardiovascular-related bioactivity in humans. Nutrients 11, 2288 (2019).

33. Miyaichi, Y., Segawa, A. \& Tomimori, T. Studies on Nepalese crude drugs. xxix. chemical constituents of dronapuspi, the whole herb of Leucas cephalotes S Preng. Pharm. Bull. 54, 1370-1379 (2006).

34. Kellam, S. J., Mitchell, K. A., Blunt, J. W., Munro, M. H. \& Walker, J. R. Luteolin and 6-hydroxyluteolin glycosides from Hebe stricta. Phytochemistry 33, 867-869 (1993).

35. Huang, C., Wei, P., Fan, K., Liu, Y. \& Lai, 3C-like proteinase from SARS coronavirus catalyzes substrate hydrolysis by a general base mechanism. Biochemistry 43, 4568-4574 (2004).

36. Muramatsu, T. et al. SARS-CoV 3CL protease cleaves its C-terminal autoprocessing site by novel subsite cooperativity. Natl. Acad. Sci. U.S.A. 113, 12997-13002 (2016).

37. Ghosh, A. K., Chapsal, B. D., Weber, T. \& Mitsuya, H. Design of HIV protease inhibitors targeting protein backbone: an effective strategy for combating drug resistance. Acc. Chem. Res. 41, 78-86 (2008).

38. Chinchansure, A. A. et al. Leucas mollissima, a source of bioactive compounds with antimalarial and antimycobacterium activities. Planta Med. Lett. 2, e35-e38 (2015).

39. Antariksh, K., Kumar, P. C., Kumar, T. A. \& Pradeep, S. Phytochemical investigation and antimicrobial activity of Leucas cephalotes Spreng whole herb. Der Pharm. Lett. 2, 284-296 (2010).

40. Yi, Small molecules blocking the entry of severe acute respiratory syndrome coronavirus into host cells. J. Virol. 78, 11334-11339 (2004).

41. Fan, W., Qian, S., Qian, P., \& Li, X. (2016). Antiviral activity of luteolin against Japanese encephalitis virus. Virus research, 220, 112-116.

42. Mehla, R., Bivalkar-Mehla, S., \& Chauhan, A. (2011). A flavonoid, luteolin, cripples HIV-1 by abrogation of tat function. Plos one, 6(11).

43. Patel, N. K., Khan, M. S. \& Bhutani, K. K. (2015). Investigations on Leucas cephalotes (Roth.) Spreng. for inhibition of LPS-induced pro-inflammatory mediators in murine macrophages and in rat model. EXCL/ J. 14, 508-516.

44. Rojas, Á. et al. Effect of quercetin on hepatitis C virus life cycle: from viral to host targets. Rep. 6, 1-9 (2016). 
45. Zandi, K., Teoh, B. T., Sam, S. S., Wong, P. F., Mustafa, M. R., \& AbuBakar, S. Antiviral activity of four types of bioflavonoid against dengue virus type-2. J. 8, 560 (2011).

46. Lee, J. S., Kim, H. J. \& Lee, Y. S. A new anti-HIV flavonoid glucuronide from Chrysanthemum morifolium. Planta Med. 69, 859-861(2003).

47. Chen, Y. W., Yiu, C. P. B. \& Wong, K. Y. Prediction of the SARS-CoV-2 (2019-nCoV) 3C-like protease (3CL pro) structure: virtual screening reveals velpatasvir, ledipasvir, and other drug repurposing F1000Res. 9, https://doi.org/10.12688/f1000research.22457.1 (2020).

48. Wu, C. et al. Analysis of therapeutic targets for SARS-CoV-2 and discovery of potential drugs by computational Acta Pharm. Sin. B. https://doi.org/10.1016/j.apsb.2020.02.008 (2020).

49. Balkrishna, A., Pokhrel, S., Singh, J. \& Varshney, A. Withanone from Withania somnifera may inhibit novel coronavirus (COVID-19) entry by disrupting interactions between viral s-protein receptor binding domain and host ACE2 receptor. J. https://doi.org/10.21203/rs.3.rs-17806/v1 (2020)

50. Wan, S. et al. Clinical features and treatment of COVID-19 patients in northeast chongqing. Med. Virol. https://doi.org/10.1002/jmv.25783 (2020).

51. Coronavirus disease (COVID-19) outbreak (World Health Organization, 2020); https://www.who.int/emergencies/diseases/novel-coronavirus-2019

52. Ludvigsson, J. F. Systematic review of COVID-19 in children show milder cases and a better prognosis than adults. Acta Paediatr. https://doi.org/10.1111/apa.15270 (2020).

53. Hanwell, M. D. et al. Avogadro: an advanced semantic chemical editor, visualization, and analysis platform. Cheminform. 4, 17 (2012).

54. Grosdidier, A., Zoete, V. \& Michielin, O. EADock: docking of small molecules into protein active sites with a multiobjective evolutionary optimization. Proteins 67, 1010-1025(2007).

55. Mishra, R. C., Kumari, R., Yadav, S. \& Yadav, J. P. Target based virtual screening of new leads inhibitor against bacterial cell division protein FtsZ for the discovery of antibacterial agents. Chem. 16, 169175 (2020). .

\section{Tables}

Table 1 Lead molecules with binding energy formed H-bonds with amino acids of 3CLpro 


\begin{tabular}{|c|c|c|c|c|c|}
\hline Compounds & $\Delta$ Gbind Kcal/Mol & $\begin{array}{l}\text { Total } \\
\text { fitness } \\
\text { score } \\
\text { Kcal/Mol }\end{array}$ & $\begin{array}{l}\mathrm{H} \\
\text { Bonds }\end{array}$ & $\begin{array}{l}\text { Amino acids of } \\
\text { CLPro form H-bond } \\
\text { with ligand at Zero } \\
\text { Cluster }\end{array}$ & $\begin{array}{l}\text { Predicted } \\
\mathrm{LD}_{50} \\
\mathrm{mg} / \mathrm{kg}\end{array}$ \\
\hline Cordifolin & -8.77 & -1167.40 & 5 & $\begin{array}{l}\text { Leu4, Ser46, } \\
\text { Asn142, }\end{array}$ & 2100 \\
\hline & & & & $\mathrm{Gln} 189$ & \\
\hline Anisofolin A & -8.72 & -1193.74 & 1 & Leu4 & 5000 \\
\hline $\begin{array}{l}\text { Apigenin } \\
\text { glucoside }\end{array}$ & -8.36 & -1182.99 & 3 & Gly71, Asn119 & 5000 \\
\hline Luteolin & -8.35 & -1295.38 & 1 & Phe219 & 3919 \\
\hline Laballenic acid & -8.13 & & 1 & Lys97 & 2500 \\
\hline Quercetin & -8.04 & -1251.14 & 1 & Arg105 & 159 \\
\hline $\begin{array}{l}\text { Luteolin-4- } \\
\text { glucoside }\end{array}$ & -7.87 & -1176.55 & 1 & Glu240 & 5000 \\
\hline $\begin{array}{l}\text { Sofosbuvir } \\
\text { standard }\end{array}$ & -7.76 & -1316.74 & 1 & Lys97 & 12000 \\
\hline $\begin{array}{l}\text { Nelfinavir } \\
\text { standard }\end{array}$ & -7.51 & -1196.19 & 0 & - & 600 \\
\hline $\begin{array}{l}\text { Liponavir } \\
\text { standard }\end{array}$ & -7.60 & -1296.19 & 0 & - & 5000 \\
\hline
\end{tabular}

Table 2. Showing plant sources of lead phytoligands for SARS-CoV-2 


\begin{tabular}{llc}
\hline Compounds & Plant Sources & References \\
\hline Cordifolin & Giloy, Manjistha & 23 \\
Anisofolin A & $\begin{array}{l}\text { Dronapuspi, Jhunke Ghaans, Indian Catmint, Oriental } \\
\text { Motherwort }\end{array}$ & 24 \\
\hline $\begin{array}{l}\text { Apigenin 7- } \\
\text { glucoside }\end{array}$ & $\begin{array}{l}\text { Dronapuspi, Black Pepper, German Chamomile, } \\
\text { Celery, Penny Bun, Olive, Star Fruit, Goji Berries }\end{array}$ & $25-27$ \\
\hline Luteolin & $\begin{array}{l}\text { Dronapuspi, Parsley Leaves, Celery, Black Pepper, } \\
\text { Olive Oil, Rosemary, Lemons, Peppermint, Sage, }\end{array}$ & 28 \\
& And Thyme & 29,30 \\
\hline $\begin{array}{l}\text { Laballenic acid } \\
\text { Quercetin }\end{array}$ & Dronpushpi, Lion's Ear & 31,32 \\
\hline $\begin{array}{l}\text { Luteolin-4- } \\
\text { glucoside }\end{array}$ & Onion, Garlic, Parsley Leaves, Fennel Leaves, Chili & 33,34 \\
\hline
\end{tabular}

\section{Figures}




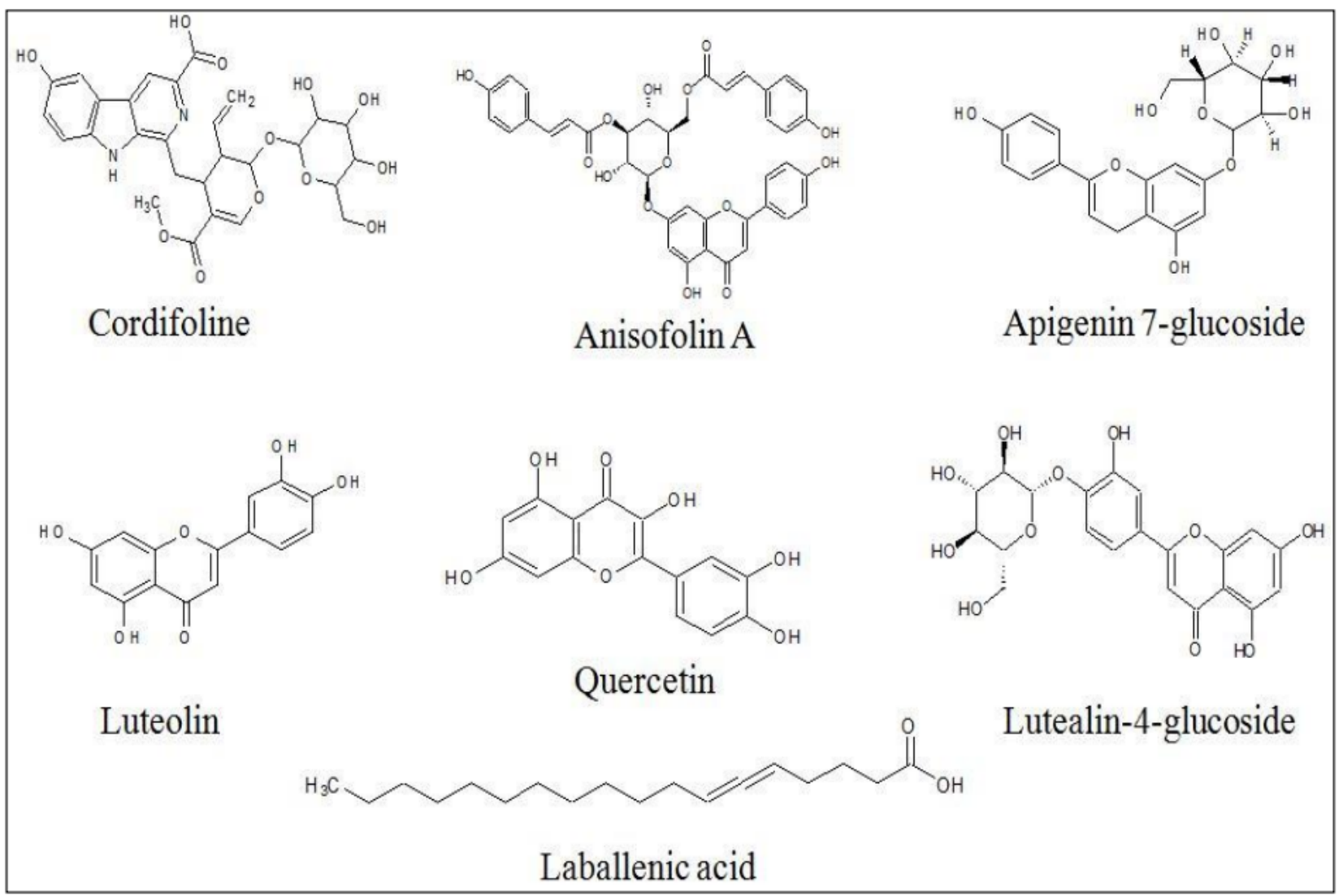

Fig.1a| Structure of lead phytoligands against 3CLpro

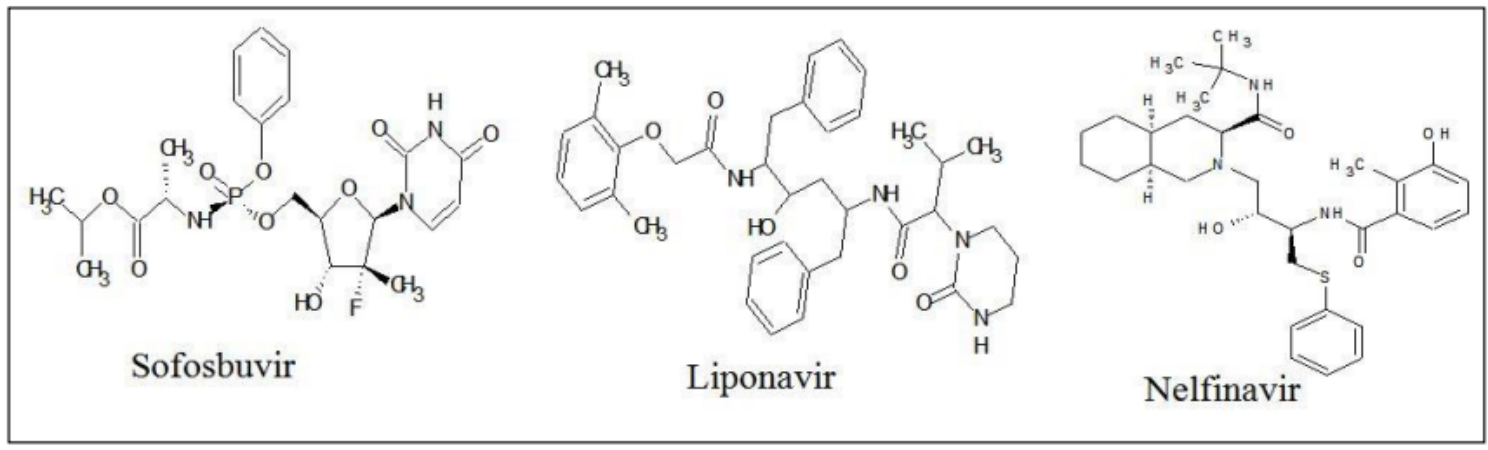

Fig.1b $\mid$ Structure of standard drugs against 3CLpro

Figure 1

a| Structure of lead phytoligands against 3CLpro. b| Structure of standard drugs against 3CLpro 


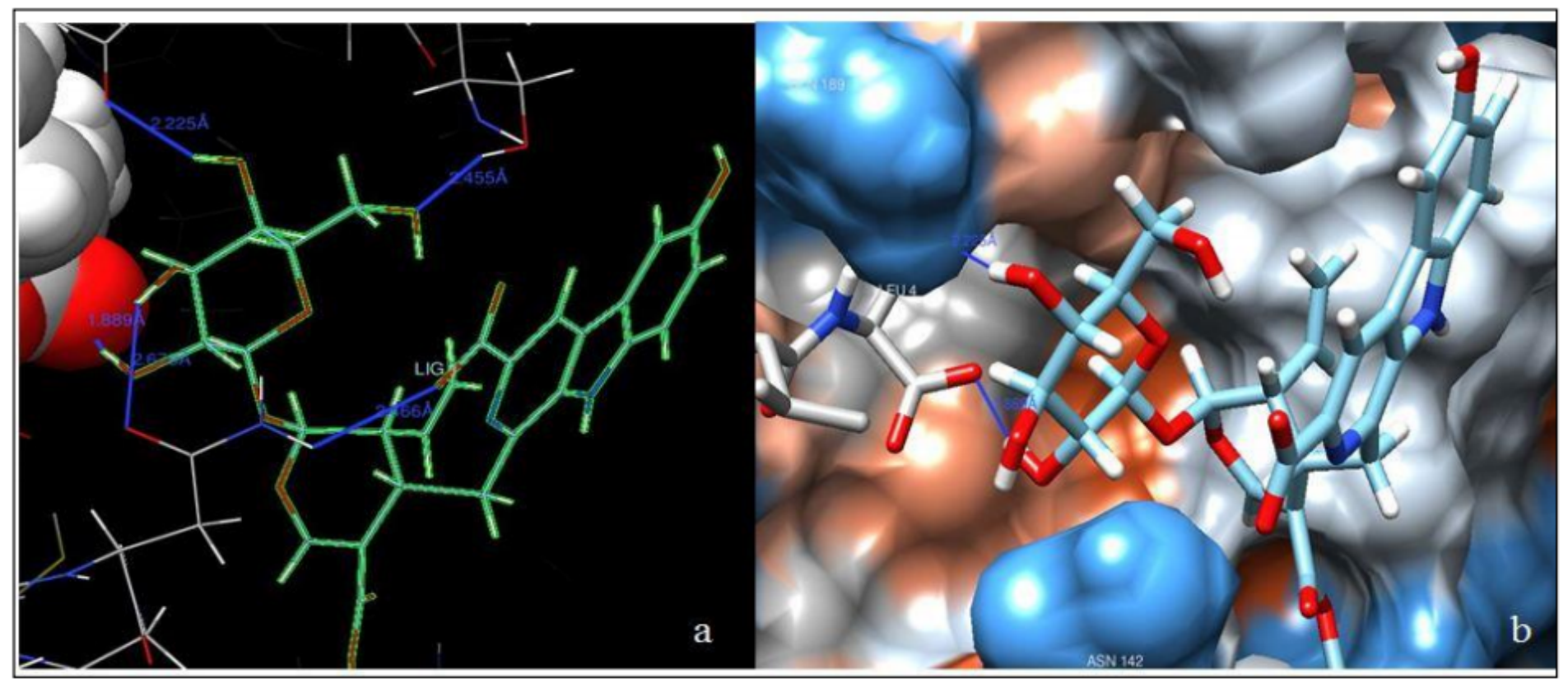

Figure 2

Binding view of 3CLpro and cordifolin (a) Ribbon structure, where blue line shows $\mathrm{H}$ - bonds (b) Protein surface shows in brown color represents hydrophobic interaction and blue color represents hydrophilic interaction with cordifolin

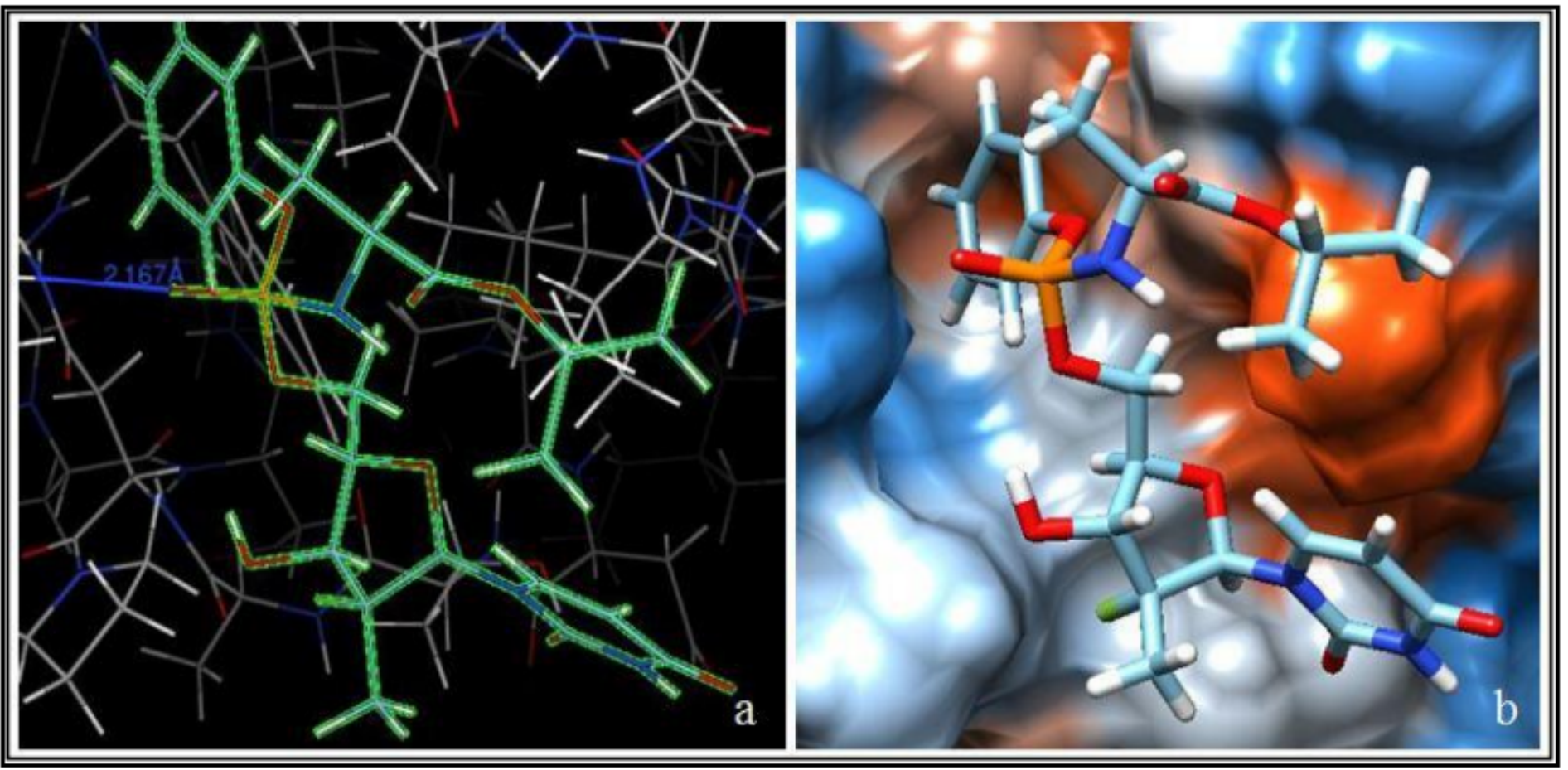

Figure 3

Detail representation of binding residue of 3CLpro with (a) Anisofolin A (b) Apigenin 7- glucoside (c) Luteolin (d) Laballenic acid (e) Quercetin and (f) Luteolin-4-glucoside 

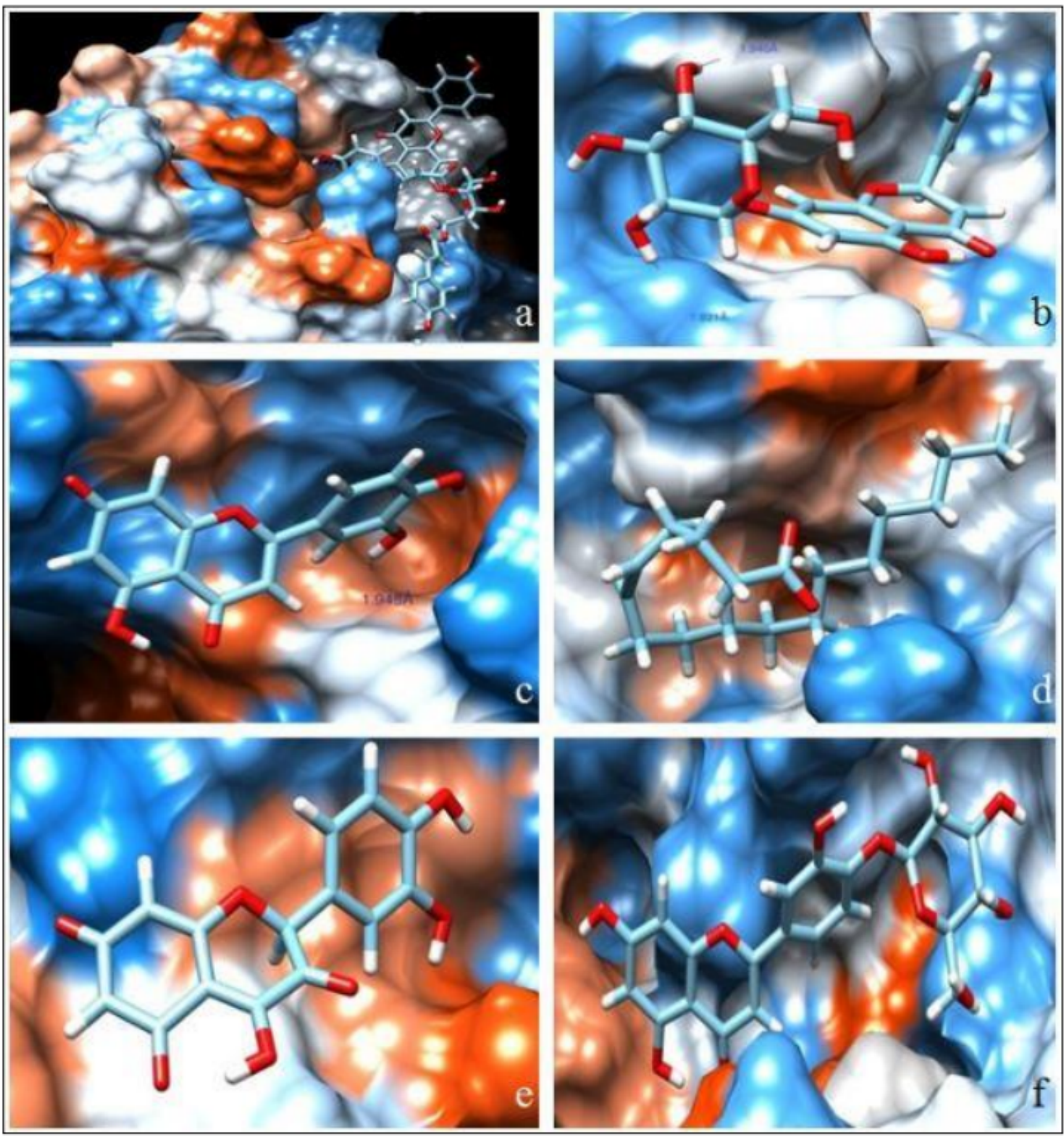

\section{Figure 4}

Binding affinity of 3CLpro and sofosbuvir (a) Ribon structure, where blue line show $\mathrm{H}$ - bond (b) Blue surface of enzyme shows hydrophilic and red color shows hydrophobic interaction with standard drug

\section{Supplementary Files}


This is a list of supplementary files associated with this preprint. Click to download.

- SupplementalTable1.pdf 